\title{
EVIDENCE FOR A DEFICIENCY IN INTER-MOLECULAR CROSS-LINKING IN COLLAGEN FIBRILS ISOLATED FROM RHEUMATOID JOINTS
}

\author{
BY \\ F. S. STEVEN \\ Department of Medical Biochemistry, Lapworth Laboratories, University of Manchester
}

Collagen fibrils can be isolated from mature uncalcified connective tissue by a preliminary treatment with crude bacterial $a$-amylase. This type of collagen fibril has been described as Nishihara collagen (Steven, 1964). Amino acid analyses of Nishihara collagen preparations indicate that the fibrils are a highly purified form of collagen, containing less of the impurities which are often found in trace amounts in preparations of acid soluble collagen (Steven, in preparation). Electron microscopic examination of reconstituted acid soluble collagen fibrils and Nishihara collagen fibrils indicate that both are made up of collagen molecules (tropocollagen monomers) polymerized laterally and endto-end. Reconstituted collagen fibrils are held together by non-covalent bonds, e.g. ionic, hydrogen, and hydrophobic bonds. However, Nishihara collagen fibrils have in addition a second type of stabilizing force, covalent cross-linkages between monomers, which confer stability on the fibril towards physical and biological destruction. Nishihara collagen provides us with purified samples of naturally-occurring collagen at the fibrillar level.

Nishihara collagen fibrils isolated from rheumatoid knee joints were previously demonstrated to be more susceptible to proteolytic digestion by pronase than were collagen fibrils isolated from normal synovia (Steven, 1965). Chemical studies (Steven, 1966) have indicated the presence of at least two distinct types of covalent intermolecular crosslinkages in mature collagen fibrils. One type of cross-linkage is destroyed by hydroxylamine and may be considered to be "ester-like" and a second type is destroyed in cold alkali. It was therefore of special interest to compare this system of intermolecular cross-linking bonds in normal and rheumatoid collagen fibrils. The present work outlines the results of this study without giving all the chemical evidence which was necessary to prove the presence of two or more types of cross-linkages in mature collagens.

\section{Experimental Conditions}

Synovia were removed post mortem from the knee joints of five subjects with no known history of connective tissue disease. Samples, examined by Dr. J. Ball, were shown to be histologically normal.

Six rheumatoid patients underwent synovectomy and the synovium plus some adhering capsule was used in each case as the source of the collagen fibrils. Tissue samples from these patients were examined histologically and all six subjects were confirmed to be typical rheumatoid cases.

The tissues were defatted with acetone and the collagen fibrils isolated by the Nishihara technique.

Preliminary studies indicated that, after treatment with hydroxylamine, both normal and rheumatoid collagens retained enough resistant cross-linkages to prevent the solubilization of 70 to 80 per cent. of the original collagen fibrillar nitrogen during thermal denaturation. Thus hydroxylamine degradation could not distinguish between normal and rheumatoid collagen fibrils. On the other hand alkaline degradation was found to be much more effective on collagen from rheumatoid tissue than on normal synovial collagen.

The alkaline degradation technique is based on the procedure described by Hey and Stainsby (1965). The collagen fibrils prepared by the Nishihara technique were suspended in $2 \mathrm{~N}$. $\mathrm{NaOH}$ at $4^{\circ} \mathrm{C}$. for 6 days. The reaction mixture was then brought to $p \mathrm{H} 7$ with $\mathrm{N}$ acetic acid and allowed to equilibrate at room temperature for 1 hour. The suspended fibrils were then placed in a boiling water bath for 1 hour. The amount of nitrogen in the soluble gelatin produced during boiling and also the amount of nitrogen in the insoluble residue were determined by microkjeldahl nitrogen analysis. The amount of total nitrogen in the fibrils initially was obtained by summation of the nitrogen values obtained for the soluble and insoluble fractions. The results are presented as the amount of total nitrogen in the insoluble residue expressed as a percentage of the total nitrogen content initially present in the intact collagen fibrils.

\section{Results}

In control experiments, the amount of gelatin produced on boiling rheumatoid collagen fibrils which had not been subjected to alkaline degradation was 
determined. In all cases these yielded 2 to 5 per cent. soluble nitrogen, i.e. 95 to 98 per cent. insoluble residue remained.

It was noted that the collagen from normal synovia after alkaline treatment underwent marked thermal shrinkage during boiling with the formation of a compact pellet of insoluble residue. The rheumatoid collagen after similar treatment disintegrated on heating to yield a suspension of very fine particles. The percentages of initial nitrogen remaining in the insoluble residue after alkaline degradation and boiling are presented in the form of a histogram in Fig. 1. It is clear that this treatment degrades the rheumatoid collagens to a much greater extent than normal collagens. The average insoluble residue is $\mathbf{7 0}$ and $\mathbf{1 3}$ per cent. respectively for normal and rheumatoid fibrils.

\section{Discussion}

Either an enzyme (pronase: Steven, 1965) or alkali degradation has each been shown to be capable of distinguishing between collagen fibrils isolated from normal and rheumatoid joint tissue. Both these treatments attack the collagen fibrils at, or close to, the sites of intermolecular cross-linking. It can, therefore, be stated that, in rheumatoid tissue, part or all of the collagen fibrils are defective in one type of cross-linkage which is partly responsible for the polymerization and stability of tropocollagen units within the fibril structure. Furthermore, these defective linkages are not those labile to alkali but are those that remain after alkali treatment, since it is these remaining cross-linkages which prevent the solubilization of the treated collagen during boiling.
The alkali-labile bonds should be destroyed with $\underset{\widetilde{D}}{\mathrm{~J}}$ equal ease in both normal and rheumatoid collagens

(Fig. 2).

$\sim$ Cross-linkages destroyed by hydroxylamine Cross-linkages destroyed by alkali

Normal collogen

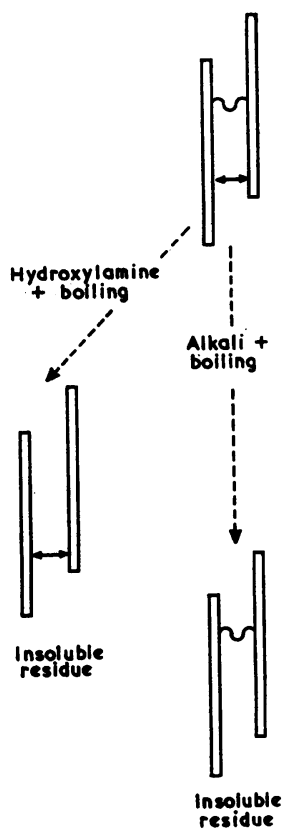

Rheumatoid collagen

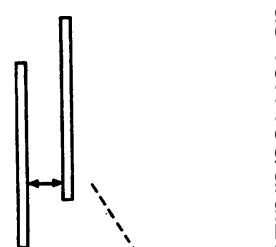

Hydroxylamine

bolling i
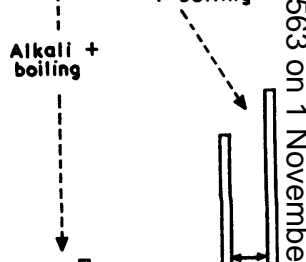

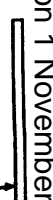

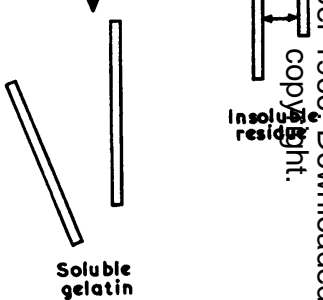

Fig. 2.-Simplified model for hydroxyla mine and alkali degradation of crosslinkages between collagen monomers in Nishihara collagen fibrils.

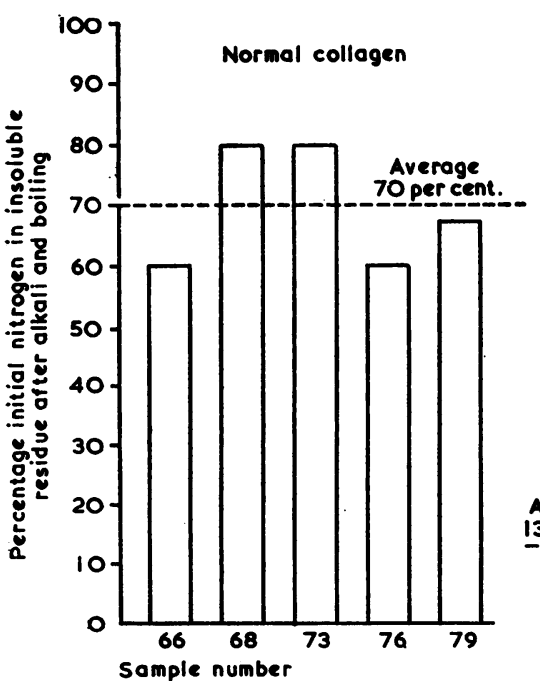

Rheumatoid collagen

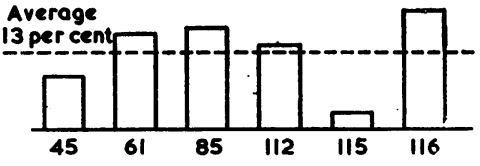

Fig. 1.-Percentages of initial nitroge remaining in normal and rheumatoif collagen after alkaline degradation and boiling. 
This defect of cross-linking observed in rheumatoid collagen may be explained by at least two different hypotheses:

(1) The rheumatoid fibrils may be immature and thus deficient in this particular type of cross-linked stability. The growth of the rheumatoid synovia during the active stage of the disease would favour the formation of fibrils which are immature relative to the collagen of normal synovia. Immature collagen fibrils isolated from calf Achilles tendon also show this same susceptibility to alkali degradation (Steven, 1966).

The thermal stability of untreated rheumatoid collagen fibrils indicates that at least part of the cross-linking system is normal in rheumatoid collagens. It would appear that rheumatoid fibrils reach a partially cross-linked state, but lack the cross-linkages which are resistant to alkali in normal synovial collagen. Kellgren and Ball (1950) have drawn attention to the appearance of histologically mature and immature collagen fibrils in rheumatoid tendons.

(2) It is possible that the collagen fibrils of rheumatoid synovia are cross-linked in the normal manner but may become defective from exposure to the action of proteolytic enzymes released during the acute stage of the inflammatory response. Frankland and Wynn (1962) claimed that tropocollagen was attacked by lysosomal enzymes, and Delaunay and Bazin (1965) have demonstrated the digestion of insoluble polymerized collagen by enzymes released during experimental inflammation. Collagen isolated from inflamed tissue might then be expected to be partially destabilized and thus more susceptible to alkaline degradation.

At the present time it is impossible to decide which of these two hypothese is correct. It may well be that the cathepsins described by Delaunay and Bazin (1965) influence the turnover rate of collagen in inflamed tissue, with the result that collagen is both degraded and synthesized more rapidly than in normal synovia. Further insight on this problem will require an extensive examination of collagens isolated froni both immature and inflamed nonrheumatoid tissues.

It can be concluded that collagen fibrils isolated from rheumatoid tissue are defective in one type of covalent cross-linkage and are less resistant to enzymic and alkali degradation than collagen fibrils from normal synovial tissue.

\section{Summary}

Mature collagen fibrils are formed from tropocollagen monomers by lateral and longitudinal polymerisation through two or more distinct types of chemical cross-linkages. One type of cross-linkage is destroyed by cold alkali treatment. Collagen fibrils were isolated by an enzymic method from normal knee joint synovial tissue and from synovia plus adhering capsule removed from rheumatoid knees at synovectomy. After alkaline treatment normal synovial collagen fibrils contained sufficient alkali stable cross-linkages to resist solubilisation after boiling at neutral $\mathrm{pH}$. Rheumatoid collagens were shown to be deficient in these alkali stable cross-linkages and were readily depolymerised by boiling at neutral $\mathrm{pH}$.

This lack of cross-linking would explain the previously reported susceptability of rheumatoid collagen to pronase digestion, whereas normal collagen was resistant to digestion under the experimental conditions.

I wish to thank Dr. J. Ball for his help in providing histological examinations of the tissues used in this work and for helping to prepare this manuscript, Mrs J. Knott for her excellent technical assistance, and Prof. D. S. Jackson for his many stimulating and helpful discussions.

\section{REFERENCES}

Delaunay, A., and Bazin, S. (1965). In "Structure and Function of Connective and Skeletal Tissue: Proceedings of an Advanced Study Institute organized under the Auspices of N.A.T.O., Sto Andrews, 1964", p. 472 . Scientific committee S. F. Jackson, R. D. Harkness, S. M. Partridge and G. R. Tristram. Butterworth, London.

Frankland, D. M., and Wynn, C. H. (1962). Biochem. $J ., 85,276$.

Hey, C. D., and Stainsby, G. (1965). Biochim. biophys. Acta, 97, 364.

Kellgren, J. H., and Ball, J. (1950). Ann. rheum. Dis., 9, 48.

Steven, F. S. (1964). Ibid., 23, 300.

$$
\text { (1965). Ibid., 24, } 473 .
$$

(1966). Biochim. biophys. Acta, in press.

Mise en évidence d'une déficience des liaisons croisés (cross-linking) intermoléculaires dans les fibrilles collagènes isolées à partir d'articulations rhumatoïdes

\section{RÉSUMÉ}

Les fibrilles collagènes matures se forment à partir de monomères de tropocollagène par polymérisation latérale et longitudinale par deux types distincts ou plus de cross-linkage chimique. Un type de cross-linkage est détruit par alcalinisation à froid. Les fibrilles collagènes ont été isolées par un procédé enzymatique à partir de tissu synovial provenant d'un genou normal et à partir de fragment de synoviale et de capsule articulaire qui y adhérait, prélevés au cours de synovectomie sur des genoux atteints d'arthrite rhumatismale. Après alcalinisation les fibrilles collagènes issues des synoviales normales contenaient des cross-linkages suffisamment stables pour résister à la solubilisation par ébullition à pH neutre. Les tissus collagènes des sujets atteints d'arthrite rhumatismale accusèrent une défaillance de ces 
cross-linkages résistant à l'alcalinisation et furent aisement dépolymérisés par l'ébullition à $\mathrm{pH}$ neutre.

Ce manque de liaisons croisées expliquerait la susceptibilité déjà rapportée du tissu collagène de l'arthrite rhumatismale à la digestion par la pronase, alors que le tissu collagène normal était résistant à cette digestion dans les conditions de l'expérience.

Demostración de una deficiencia en uniones intermoleculares (cross-linking) en fibrillas colágenas aisladas de las articulaciones reumatoides

\section{SUMARIO}

Fibrillas colágenas maduras se forman de monómeros tropocolágenos en polimerización lateral y longitudinal por medio de dos o más tipos distintos de unión química.
Uno de ellos es destruido por alcalinización en tempera- $\frac{\mathcal{D}}{\sigma}$ tura ambiente. Las fibrillas colágenas fueron aisladas por un proceso enzimático del tejido sinovial de una rodilla normal y de un fragmento de la sinovia y cápsula adherente, removida en el curso de sinovectomías de $\overline{\text { ? }}$. rodillas reumatoides. Después de alcalinización las fibrillas colágenas de la sinovia normal contenían uniones $\overrightarrow{\vec{T}}$ suficientemente estables para resistir solubilización después de ebullición a un pH neutral. Fibrillas colágenas de sujetos con artritis reumatoide demostraron una deficiencia de estas uniones alcalino-resistentes y fueron $\frac{\text { s }}{}$ rapidamente despolimerizados por ebullición a un $\mathrm{pH}_{\varrho}^{\Phi}$ neutral.

Esta falta de uniones puede explicar la susceptibilidadô ya descrita del tejido colágeno reumatoide a la digestión $\vec{\circ}$ por la pronasa, mientras que el tejido colágeno normal: fué resistente a esta digestión bajo condiciones experi- $\vec{\omega}$ mentales. 